\title{
Forced Marriage as a Harm in Domestic and International Law
}

Catherine Dauvergne ${ }^{\oplus}$ and Jenni Millbank ${ }^{\wp}$

This is a pre-publication version which appears in (2010) 73 Modern Law Review 57-88. The definitive version is available at www.blackwell-synergy.com

\section{INTRODUCTION}

This article explores the disjuncture between domestic legal and political responses to forced marriage faced by nationals of Western states with the response of refugee law to forced marriages occurring elsewhere. The framework of international human rights suggests that forced marriage should be a paradigm example of 'persecution', the central criterion for any refugee claim. Yet our analysis of refugee decisions in Australia, Canada, and the United Kingdom revealed a profound and on-going reluctance to accept that forced marriage was, in and of itself, a persecutory harm.

The issue of forced marriage emerged in Europe in the mid 1990s as a locus of considerable public and political concern. Attention focused on young women from first or second generation immigrant backgrounds forced or pressured to marry men from their parent's country of origin. Although paternalistically framed, and arguably informed by racist tropes of cultural 'tradition', family 'honour' and immigration 'convenience' or fraud, some of these domestic initiatives were also motivated by feminist and migrant women's groups and involved active and on-going commitment to ensuring young women's sexual and social agency. These domestic initiatives are starkly at odds with how forced marriage appears in refugee law, where a threatened or actual forced marriage is rarely held to trigger protection obligations.

The article opens with an examination of forced marriage in international human rights law, and examines how European states have adjusted domestic immigration, criminal and family

\footnotetext{
${ }^{\oplus}$ Canada Research Chair in Migration Law, UBC, Canada.

$\wp$ Professor of Law, UTS, Australia. This research was supported by a grant from the Australian Research Council. Thanks to Katherine Fallah, Marianna Leishman and Anthea Vogl for their research assistance.
} 
law provisions in recent years in response to a surge in public and political mobilisation. We then turn to the centrepiece of our analysis, the case set of 120 refugee decisions involving a claim of forced marriage as persecution. This case set includes all available decisions in English over the past fifteen years from the United Kingdom, Canada and Australia. (Because of marked differences in US asylum law, policy and procedure, our analysis of the available US cases is published separately. ${ }^{1}$ ) Our analysis considers how these cases address the key areas of refugee jurisprudence in forced marriage claims: persecution, nexus, credibility and membership in a particular social group. The final section of the paper is an examination of the work of Britain's Forced Marriage Unit. The Forced Marriage Unit is a unique government entity, providing a range of assistance, including extraterritorial assistance, in response to individual requests for state protection in avoiding and escaping forced marriage. Yet, strikingly, British refugee jurisprudence has evinced a deep and ongoing resistance to forced marriage claims in comparison with Canada and Australia, where forced marriage has not yet emerged as a major domestic policy issue.

We conclude that forced marriage provides a key site for understanding and explaining the persistent failure of refugee law to fully embrace human rights norms, especially as they relate to gender and sexuality. This failure is caused by the structure of refugee law, which is erected on a foundation of 'othering' and is sustained by a recurrent division between 'us' and 'them'. This dichotomy means that refugee law endlessly replicates a division between the prosperous, benevolent, liberal and rights respecting West, and the impoverished and encultured others who threaten to overwhelm 'us' if the floodgates are not kept tightly closed. While we acknowledge that there are many valid criticisms to be made of international human rights discourse generally and domestic initiatives on forced marriage specifically, our analysis in this article reflects our belief that meaningful consent to marriage is nevertheless an issue of vital importance. We proceed from the premise that the state has a role, indeed a duty, in protecting consent to marriage that extends to responding to claims for assistance from citizens and, in some circumstances, non-citizens. ${ }^{2}$

\footnotetext{
${ }^{1}$ See C. Dauvergne and J. Millbank, 'Forced Marriage and the Exoticisation of Gendered Harms in US Asylum Law' (2010) 19 Columbia Journal of Gender and Law, forthcoming.

2 The discussion in this article focuses mainly upon the context of refugee law, however we are aware that requests for state assistance in responding to forced marriage are far broader, and include for example
} 


\section{FORCED MARRIAGE CLAIMS IN INTERNATIONAL LAW}

The choice of whether, and whom, to marry is so intimately connected to self determination that it has been acknowledged in several key international instruments as a fundamental human right. The requirement that marriage be undertaken only with the 'free and full consent' of both parties was first enshrined in Article 16(2) of the 1948 Universal Declaration of Human Rights (UDHR) and was soon after reiterated in several instruments which can directly bind states: Article 23(3) of the International Covenant on Civil and Political Rights (ICCPR) in 1966 and Article 1(1) of the Convention on Consent to Marriage in 1962. The International Covenant on Economic, Social and Cultural Rights (ICESCR) in 1966 used the more limited language of 'free consent' in Article 10(1). In 1979 the Convention on the Elimination of all Forms of Discrimination against Women (CEDAW) addressed marriage rights in greater detail (including equality of status within marriage, rights over property and rights with regard to children) in recognition of the fact that historically marriage has been a key site of women's inferior legal status and social subordination. CEDAW Article 16(1)(b) expanded the language of consent to include, 'The same right freely to choose a spouse and to enter into marriage only with their free and full consent'.

Given how marriage has been understood in human rights law, one would expect that the issue of forced marriage would find a direct fit in the framework of refugee law. Our study of forced marriage instead demonstrates a stark disjuncture between refugee jurisprudence and human rights jurisprudence. At international law, a refugee is someone who:

owing to a well-founded fear of being persecuted for reasons of race, religion, nationality, membership of a particular social group or political opinion, is outside the country of his nationality and is unable, or owing to such a fear, is unwilling to avail himself of the protection of that country; or who, not having a nationality and being outside the country of his former habitual residence as a result of such events, is unable or, owing to such fear, is unwilling to return to it. ${ }^{3}$

\footnotetext{
domestic violence protection orders, nullity of marriage applications, sexual assault complaints, wardship proceedings and claims for emergency housing.

${ }^{3}$ Article 1(a)(2) of the 1951 Convention Relating to the Status of Refugees 189 UNTS 150, as amended by the 1967 Protocol Relating to the Status of Refugees 606 UNTS 267.
} 
On the basis of this definition, international refugee law provides 'surrogate' protection for individuals whose country of nationality cannot or will not protect them from certain types of harm. It is clear in the jurisprudence that states will not be held to the standard of protecting their citizens from every breach of an international human rights standard: some breaches constitute being persecuted and others do not. While the protection offered by refugee law is not identical to that offered by international human right law, it should be related to, and intelligible through, international human rights standards. ${ }^{4}$

In his influential 1991 book James Hathaway argued that, 'persecution is most appropriately defined as the sustained or systematic failure of state protection in relation to one of the core entitlements which has been recognised by the international community'. In defining core entitlements Hathaway proposed a four tiered human rights approach to persecution, organising human rights statements according to the degree of obligation they place on states. First and second tier rights are those enunciated in the UDHR and made binding by their inclusion in the ICCPR and the ICESCR. The first tier comprises non-derogable rights such as freedom from arbitrary deprivation of life, protection from torture and cruel inhuman and degrading treatment, freedom from slavery, the right to recognition as a person in law and freedom of thought, conscience and religion. The second tier comprises rights which are derogable only in cases of national emergency, such as freedom from arbitrary arrest or detention and the rights to marriage, privacy and family life with which we are concerned here. Any breach of the first tier and discriminatory or non-emergency breaches of the second tier would ordinarily be defined as persecutory. ${ }^{6}$ Thus following

\footnotetext{
${ }^{4}$ See eg D. Anker, 'Refugee Law, Gender, and the Human Rights Paradigm' (2002) 15 Harvard Human Rights Journal 133; K. Daley and N. Kelly, 'Particular Social Group: A Human Rights Based Approach in Canadian Jurisprudence' (2000) 12 International Journal of Human Rights Law 148.

${ }^{5}$ James Hathaway, The Law of Refugee Status (Toronto: Butterworths, 1991) 112.

${ }^{6}$ ibid, 108-110. The third tier rights are those found in the UDHR and contained within the ICESCR, which, unlike the ICCPR does not impose immediately enforceable standards upon states. Third tier values include the right to work, entitlement to food, clothing, housing, medical care and basic education, as well as protection of the family. Fourth tier entitlements are rights recognised in the UDHR but not elsewhere codified. They include the right to own property and the right to be protected from unemployment. While severe or discriminatory breaches of the third tier could in some circumstances be persecutory, breaches of the fourth tier would very rarely be so under any circumstance.
} 
Hathaway, forced marriage should be clearly understood as persecutory harm. ${ }^{7}$ Moreover, forced marriage (in the context of abduction by soldiers during war) has recently been recognised in international humanitarian law as an 'inhuman act' independent of sexual assault and sexual slavery. ${ }^{8}$

Forced marriage has been explicitly acknowledged as a gender-related form of persecution in a number of national and international refugee law documents. The Canadian guidelines on gender related persecution, first released in 1993, include under their fourth category of claimants, 'Women who fear persecution as the consequence of failing to conform to, or for transgressing, certain gender-discriminating religious or customary laws and practices in their country of origin' adding as an example women who violate such norms by 'choosing their own spouses' ${ }^{9}$, and in a later section include 'female-specific experiences' of persecution such as forced marriage. ${ }^{10}$ Likewise the 1996 Australian gender guidelines note forced marriage as the third of four examples of 'gender-based treatment against women' which may constitute persecution. ${ }^{11}$ Forced marriage was included in the original 2000 United Kingdom refugee tribunal gender guidelines under 'gender specific forms of harm' ${ }^{12}$ Revised (and greatly truncated) UK gender guidelines that now only operate at bureaucratic level also reference forced marriage as a form of persecution and draw attention to

\footnotetext{
${ }^{7}$ Notably, the original 2000 UK Gender Guidelines expressly endorsed the Hathaway human rights approach, while the current guidelines do not do so: see $n 12$ below and $n 13$ below.

${ }^{8}$ See Prosecutor v Brima, Kamara and Kanu SCSL-2004-16-A, Armed Forced Revolutionary Council (AFRC) Appeals Chamber Decision (22 February 2008); Prosecutor v Sesay, Kallon and Gbao SCSL-04-15-T RUF, (Revolutionary United Front) Trial Chamber judgment (25 February 2009).

${ }^{9}$ Canada: Immigration and Refugee Board, 'Guideline 4, Women Refugee Claimants Fearing Gender-Related Persecution' (1996), s A I 4.

${ }^{10} \mathrm{ibid}$, section B, 'Considerations'.

${ }^{11}$ Australia, Department of Immigration and Multicultural Affairs, 'Guidelines on Gender Issues for Decision Makers' (July 1996) 17.

12 Immigration Appellate Authority (UK), 'Gender Asylum Guidelines' (2000) at [1.13]; see also [2A.24] and a specific acknowledgement of the role of marriage in violating the human rights of lesbians and gay men at [2A.25]. These guidelines operated at Tribunal level, and drew heavily upon a model developed in 1998 by the NGO Refugee Women's Legal Group. When the Tribunal was abolished and reconstituted in 2005 the new Tribunal determined that it was not bound by its predecessor's guidelines: Asylum Aid, 'Submission of Evidence to the Independent Asylum Commission', 27 July 2007 at [40].
} 
marriage rights in assessing the objective likelihood of gender based harms. ${ }^{13}$ While the 2002 UNHCR gender guidelines refer only in passing to forced marriage as a form of persecution, ${ }^{14}$ the 2008 UNHCR guidance note on sexual orientation identifies the issue as one of importance and deals with it in some detail. ${ }^{15}$ Yet these standards were rarely utilised in analysis of whether those forced to marry form a 'particular social group' under the Refugee Convention or whether forced marriage constitutes a form of persecution. ${ }^{16}$

\section{FORCED MARRIAGE IN DOMESTIC LAW}

\section{European developments}

Beginning in the early 1990s, forced marriage emerged as a matter of public concern in a number of European countries, with a series of high profile individual cases widely reported in the media. ${ }^{17}$ In 1992, a feature story about a young Norwegian-Pakistani girl abducted by her parents and forced to marry while on a family holiday and then rescued by Norwegian authorities, gained considerable public attention. A similar event in 1997, concerning an 18 year old named 'Nadia' generated sustained political action in Norway, including a criminal conviction for abduction against her parents. ${ }^{18}$ Among several high profile cases in Britain

\footnotetext{
${ }^{13}$ UK Home Office, Asylum Policy Instructions, 'Gender Issues in the Asylum Claim' (2004, revised version 2006), topic $3 A($ iii), 4 and topic 11, 13-14.

${ }^{14}$ UNHCR, 'Guidelines on International Protection: Gender-Related Persecution within the Context of Article $1 \mathrm{~A}(2)$ of the 1951 Convention and/or its 1967 Protocol relating to the Status of Refugees', HCR/GIP/02/01 (2002) at [36], (viii): 'Female claimants may also fail to relate questions that are about 'torture' to the types of harm which they fear (such as rape, sexual abuse, female genital mutilation, 'honour killings', forced marriage, etc.)'.

15 UNHCR, 'Guidance Note on Refugee Claims Relating to Sexual Orientation and Gender Identity' (2008) especially at [13], see also [27] and [28].

${ }^{16}$ Both the UK and Australian guidelines have in general been honoured far more in the breach than the observance: see eg S. Ceneda and C. Palmer, "Lip Service" or Implementation: The Home Office Gender Guidance and Women's Asylum Claims in the UK, Asylum Aid Report (2006); S. Kneebone, 'Women within the Refugee Construct: "Exclusionary Inclusion"' in Policy and Practice - The Australian Experience' (2005) 17 International Journal of Refugee Law 7.

${ }^{17}$ The background to these developments is explored in more detail in: H. Siddiqui, "There is no "honor" in domestic violence, only shame!' in L. Welchman and S. Hossain (eds), 'Honour': Crimes, Paradigms and Violence against Women (London: Zed Books, 2005) and A. Bredal, 'Tackling Forced Marriage in the Nordic Countries: Between Women's Rights and Immigration Control', ibid.

${ }^{18}$ Bredal, ibid, 323-333.
} 
was the 1998 murder of Rukshana Naz by her brother and mother. ${ }^{19}$ By the late 1990 s, this attention led to shifts in law and policy in a number of jurisdictions, and developments have intensified in the 2000 decade. $^{20}$ The policy trajectory has varied in different states but in each case, two themes have been constant: forced marriage is an undeniable 'wrong' to be eradicated by the protective, exclusionary or educative functions of the benevolent state, and coercion to marry from family and community members arises from cultural 'otherness.' 21 The twinning of these themes, combined with an implicit understanding of vulnerable brides as 'ours' and imposed grooms as 'theirs', generated an intense early focus on immigration restrictions as the 'answer' to the 'problem' of forced marriage. ${ }^{22}$

Of all European countries, Denmark directed its reform energies most explicitly and continuously towards immigration restriction. Legal changes limiting family reunification immigration provisions began in Denmark in 1998 and were tightened again in 2000, 2002 and $2004 .^{23}$ These restrictions included raising the age limit for those being sponsored or sponsoring as a spouse to 24, a reverse onus of proof requiring couples to show their marriage is voluntarily contracted, requirements for independent housing and financial capacity, a bar on spousal reunification for cousins who are married and a requirement that both spouses have a stronger 'affiliation' with Denmark than with any other country. ${ }^{24}$ The impact of such provisions extends far beyond forced marriages, but they were justified on

\footnotetext{
${ }^{19}$ Rukshana had been forced to marry a much older man chosen by her family but after several unhappy years and two children, she became involved with her childhood sweetheart and sought a divorce. She was seven months pregnant with her lover's child when she was killed.

${ }^{20}$ See eg UN Economic and Social Council, Commission on the Status of Women, Report of the SecretaryGeneral, 'Forced marriage of the girl child' (December 2007). Sherene Razack argues that this intensification is a response to the racist anti-Muslim political climate which crystallised in the West following 9/11: 'Imperiled Muslim Women, Dangerous Muslim Men and Civilised Europeans: Legal and Social Responses to Forced Marriages' (2004) 12 Feminist Legal Studies 129, 129-132.

21 See in particular Council of Europe, Parliamentary Assembly, 'Forced Marriages and Child Marriages' Committee on Equal Opportunities for Women and Men, Document 10590 (June 2005): 'The root causes of this practice lie chiefly in the tendency for traditions to become fossilised in migrant communities': at [9] and Parliamentary Assembly, Resolution 1468 (October 2005) at [1] and [2].

${ }^{22}$ See in particular Razack, n 20 above.

${ }^{23}$ Bredal, n 17 above, 342-345.

${ }^{24}$ Summarised in Bredal, ibid, 343-344.
} 
the basis that the greatest vulnerability was faced by young people with little independence from their families being coerced into marriages with overseas born (often older) spouses from the same ethnic background. It was not until most of these restrictive regulations were in place that Denmark produced an 'Action Plan on Forced, Quasi-Forced and Arranged Marriages' with proposals that included objectives such as counselling, education for teachers and case workers, residential facilities and a research program. ${ }^{25}$

In contrast, Norway pursued an inverse trajectory, beginning in 1998 with an 'Action Plan' that did not focus on immigration restriction; indeed it suggested liberalising immigration policies might actually reduce incentives to forced marriage. ${ }^{26}$ The initial plan focused on education and support for victims. Immigration law changes were not introduced in Norway until 2003, and were minimal in comparison with Denmark. ${ }^{27}$ In this same year, a specific criminal provision on forced marriage was introduced in Norway, a move replicated in Germany in 2005 and Belgium in 2007. ${ }^{28}$ During the same time period, France made several changes to procedural requirements to ensure genuine consent for marriage. ${ }^{29}$

Whether the principal focus of government initiatives is immigration restriction or education and service provision for potential victims, these responses portray an ideological distinction between 'marriage for us' and 'marriage for them'. Forced marriage, in this dichotomous view, is embedded in foreign cultural practice, and in contrast makes the marriage of romantically attracted autonomous individuals - the marriage approved in Western family

\footnotetext{
${ }^{25}$ Denmark, 'The Government's Action Plan on Forced, Quasi-Forced and Arranged Marriages' (15 August 2003), at http://www.nyidanmark.dk/NR/rdonlyres/05ED3816-8159-4899-9CBBCDD2D7BF23AE/0/forced_marriages.pdf (last visited 21 May 2009).

${ }^{26}$ Bredal, n 17 above, 333-335.

${ }^{27}$ The principal change is that since 2004 the minimum age for sponsored and sponsoring spouses was raised from 18 to 21 and more stringent requirements to demonstrate financial resources if either one of them is under 23 years old. Norway revised its 'Action Plan' in 2007 with a budget of 70 million kroner: H. Tajik, 'Workshop on Combating Forced Marriage: Experience from the UK and Norwary' 4 September 2007 at http://www.regjeringen.no/nb/dep/aid/aktuelt/taler_artikler/politisk_ledelse/politisk-radgiver-hadiatajik/2007/Workshop-on-Combating-Forced-Marriage-Ex.html?id=481440 (last visited 13 July 2009).

${ }^{28}$ B. Clark and C. Richard, 'The Prevention and Prohibition of Forced Marriages - a Comparative Approach' (2008) 57 International and Comparative Law Quarterly 501, 503.

${ }^{29}$ ibid.
} 
law and policy - appear somehow 'culture free'. In addition, it obscures the role that the dislocations of migration, increasingly restrictive migration policy, and associated intergenerational disconnections, have played in creating a contemporary Westernised setting for forced marriage.

\section{The United Kingdom}

The emphasis upon immigration restrictions by European nations to address forced marriage has been criticised as anti-Muslim, intertwined with the war on terror, and punitive of immigrant women. ${ }^{30}$ In recent years some states have moved away from immigration law as the key 'remedial' site in forced marriage policy. The United Kingdom over the past decade provides an interesting example of the development of a multifaceted approach, strongly shaped by community and feminist involvement. While initial action focused on immigration, including raising the age requirements for spousal visas from 16 to 18 in 1999, it rapidly moved in a number of other directions.

In 1999 the United Kingdom government convened a working group on forced marriage which in 2000 issued a report entitled 'A Choice by Right'. This was influenced by the efforts of individual politicians, especially Margaret Moran, who represented the electorate of Luton South not far from London and Ann Cryer who represented Keighley from the north of England near York. ${ }^{31}$ The working group was set up by the Minister for Community Relations and chaired by Baroness Uddin and Lord Ahmed, both members of the House of Lords. The working group comprised seven other members, of whom six were representatives of community groups (and three of which were specifically women's organisations). ${ }^{32}$ The feminist group Southall Black Sisters (SBS) was initially part of this process, but resigned

\footnotetext{
${ }^{30}$ See eg A. Phillips and M. Dustin, 'UK Initiatives on Forced Marriage: Regulation, Dialogue and Exit' (2004) 52 Political Studies 531; Razack, n 20 above; A. Wilson, 'The Forced Marriage Debate and the British State' (2007) 49 Race and Class 25, 36.

${ }^{31}$ MP Moran has taken up the question of forced marriage as a centrepiece of her parliamentary role. She has also supported research in her electorate, see for example, N. Khanum, 'Forced marriage, family cohesion and community engagement: national learning through a case study of Luton' (March 2008). MP Cryer commissioned a 2005 study focusing on the effects of cousin marriage in British Pakistani communities.

${ }^{32}$ Working Group on Forced Marriage, A Choice by Right (2000), 28.
} 
when it became clear that the working group was considering mediation between potential victims of forced marriage and their families as an option. SBS strenuously opposed this on the basis that it would put vulnerable women at risk of further harm through contact with their families. $^{33}$

In 2005, the Home Office in conjunction with the Scottish executive issued a consultation paper, 'Forced Marriage: A Wrong not a Right', which recommended introducing a specific criminal offence of forcing a marriage, as other European countries had done previously. Following more than 100 representations from community groups and other stakeholders opposed to criminalisation for a range of reasons, including the risk of preventing reporting by victims, this proposal was abandoned. Rather than criminalisation, the United Kingdom created a range of new civil remedies under the Forced Marriage (Civil Protection) Act which passed in 2007 and came into effect in December $2008 .^{34}$ The centrepiece of the Act is the 'forced marriage protection order' designed to protect a person at risk of forced marriage, or who has already been forced to marry. ${ }^{35}$ 'Force' is defined to include threats or other psychological means, and a court may make a protection order on the application of the person in need of protection, a relevant (and statutorily defined) third party, any other person, or on its own initiative. The order can contain any prohibitions, restrictions, requirements or terms that are necessary to achieve its objectives, and it may have effect in England and Wales or in foreign territory. ${ }^{36}$ Forced marriage protection orders can be made

\footnotetext{
${ }^{33}$ Razack, n 20 above, 167. In fact the report was published with a guarded statement about mediation, and mediation was later rejected by the government as inappropriate: A Choice by Right ibid, 19.

${ }^{34}$ Forced Marriage (Civil Protection) Act 2007 (UK). Scotland is currently considering whether to pass similar legislation: see Scottish Government, ‘Forced Marriage: A Civil Remedy? Consultation Paper' (2008). Criminal charges under general law are still possible. In 2009 a three year gaol sentence was imposed by Manchester Crown Court on a mother who forced her 14 and 15 year old daughters to marry (the charges were inciting or causing a child to engage in sexual activity, arranging or facilitating the commission of a child sexual offence and intending to pervert the course of justice): P. Bainbridge, 'Mother jailed over forced marriages' Manchester Evening News, 20 May 2009; J. Narain, 'Muslim mother who forced her school-age daughters to marry their cousins is jailed for 3 years' Daily Mail, 22 May 2009.

${ }^{35}$ Forced Marriage (Civil Protection) Act 2007 (UK), s 63A. In the seven months to July 2009, 36 orders were reported to have been made: see D. Casciani, 'Forced Marriage Plea to Schools' BBC News 2 July 2009 at http://news.bbc.co.uk/2/hi/uk_news/8129466.stm (last visited 13 July 2009).

${ }^{36}$ Forced Marriage (Civil Protection) Act 2007 (UK), s 63B.
} 
ex parte and without notice. ${ }^{37}$ The order must be accompanied by an arrest power unless the court is convinced that in the circumstances this is not necessary to achieve the protection required. ${ }^{38}$ In short, the legislation creates a flexible tool, broadly modelled on earlier legislative approaches to domestic violence protection orders. The Act strenuously reinforces a pro-active role for the courts in confronting and potentially averting forced marriage. ${ }^{39}$ A key aspect of the United Kingdom's approach has been the establishment of the Forced Marriage Unit (FMU), within the Foreign and Commonwealth Office. We discuss this initiative later in the paper. At this point is it sufficient to note that the FMU has broad roles in education, support, and 'awareness raising', as well as in 'rescuing' victims of forced marriage.

Southall Black Sisters were ultimately very influential on the model adopted by government and have been recognised for their role in developing the legislation. ${ }^{40}$ Their concerns regarding mediation and conciliation were taken squarely on board to the extent that the Statutory Guidance explicitly cautions that these practices, which are favoured in other child protection and family conflict contexts, are inappropriate in cases of forced marriage. ${ }^{41}$ The guidance document requires all senior managers to ensure that staff are counselled to

\footnotetext{
${ }^{37}$ Forced Marriage (Civil Protection) Act 2007 (UK), s 63D.

${ }^{38}$ Forced Marriage (Civil Protection) Act 2007 (UK), s 63H.

${ }^{39}$ Prior to the enactment of the legislation, English courts had been progressively extending the range of their jurisdiction concerning this issue. Re M Minors [2002] EWHC 852 wardship proceedings were brought on behalf of two girls aged 13 and 15 by a solicitor as their next friend, in conjunction with efforts to repatriate them from Pakistan where they had been taken by a relative and were 'betrothed'. The Family Division of the High Court exercised both its inherent jurisdiction and statutory child welfare powers under the Children Act 1989 (UK) and explicitly characterised 'abduction and imposed marriage' as child abuse at [24]. In Re SK [2004] EWHC 3202 concerned an adult who was in Bangladesh in circumstances where friends feared that she was being held against her will and likely to be forced to marry. The Foreign Office brought proceedings in England on behalf of the woman. The Court extended the inherent jurisdiction developed in relation to incapacitated adults and medical decision-making to find that it held the jurisdiction to make orders and directions to locate the woman and to ascertain whether she was being held forcibly as well as to ascertain her 'true wishes'. See also In the Matter of a Child [2008] EWCH 1436 (Fam) extending the wardship jurisdiction and assistance provisions under the Forced Marriage Act to a dual national who had never been to the UK.
}

\footnotetext{
${ }^{40}$ Wilson, n 30 above.

${ }^{41}$ HM Government, The Right to Choose: Multi-Agency Statutory Guidance for Dealing with Forced Marriage (2008), 19.
} 
understand the dangers of family counselling, mediation, arbitration and reconciliation ${ }^{42}$ and 'are aware that relatives, friends, community leaders and neighbours should not be used as interpreters or advocates - despite any assurances from this known person'. ${ }^{43}$

While a significant advance on the immigration control and criminalisation focus of other European nations, the United Kingdom approach is not beyond critique. ${ }^{44}$ It is clear that the British state is operating here in a paternalistic mode. These initiatives are aimed at immigrant communities and much of the public discourse surrounding them is tinged with post-colonial cultural imperialism. ${ }^{45}$ Although the FMU repeatedly states that forced marriage affects all religious groups, initiatives have frequently been received in the press as relating only to Muslim families in a way which maps onto the contemporary politics of terrorism and Islamaphobia (viz: misogynist/pre-modern Muslim men mistreat 'their' women). ${ }^{46}$ While feminist groups such as SBS have articulated forced marriage as a dimension of family or domestic violence, it has often been linked to 'honour' crime as an expression of (other) culture. ${ }^{47}$ Moreover, recently government attention has returned to immigration rules. From November 2008 the age for spousal visas has been increased again,

\footnotetext{
${ }^{42}$ ibid, 19.

${ }^{43}$ ibid, 17.

${ }^{44}$ See eg Phillips and Dustin n 30 above; Wilson n 3030 above; M. Enright, 'Choice, Culture and the Politics of Belonging: The Emerging Law of Forced and Arranged Marriage' (2009) 72 MLR 331; A. Gill and S. Anitha, 'The Illusion of Protection? An Analysis of Forced Marriage Legislation and Policy in the UK' (2009) 31 Journal of Social Welfare and Family Law, forthcoming; and A. Gill and S. Anitha 'Coercion, Consent and the Forced Marriage Debate in the UK' (2009) 17 Feminist Legal Studies, forthcoming.
}

\footnotetext{
${ }^{45}$ For example, Wilson notes that when Lord Lester proposed the Civil Protection Bill he drew on the language of human rights but also placed the Bill explicitly in a (post) colonial context by referring to earlier efforts by the British colonial government in India to abolish Sati and child marriages, n 30 above, 35. The UK Employment Tribunal recently accepted that a stereotypical remark about forced marriage made in the workplace to a woman of Indian descent could constitute racial discrimination, violating the claimant's dignity, see: Richmond Pharmacology v Dhaliwal [2009] UKEAT 0458_08_1202 (employment Appeal Tribunal).
}

${ }^{46}$ See eg Z. Sardar, 'Forced marriages disgrace Islam' New Statesman 28 March 2008. Although notably a recent high profile UK criminal prosecution was against a mother: $\mathrm{n} 34$ above.

47 These need not be mutually exclusive: see eg the recent report of the House of Commons Home Affairs Committee, Domestic Violence, Forced Marriage and 'Honour'-Based Violence (2008) and Hackney Council, Domestic Violence and Hate Crimes Team, community information brochure, 'Honour Crimes and Forced Marriage' (2007). 
from 18 to $21 .^{48}$ Additional measures, soon to be implemented, include a requirement that any person sponsoring a spouse must first register a declaration of intention to marry before departing the UK. This declaration will then be examined by a caseworker, assessed against a 'risk profile' for forced marriage with the prospect that the immigration officer may interview the sponsor for further information, refer them to support services, or even refuse the visa based on 'vulnerability grounds'. ${ }^{49}$

A feminist assessment of the British initiatives is complex. While it is evident that government initiatives in this arena inescapably reflect a post-colonial framework, we argue that the State does have a duty to act in response to claims for assistance from those facing forced marriage. It is clear that many women, and some men, in the UK call upon the police and other government agencies for support in resisting coerced marriage. In this context, even flawed or problematic responses are, we believe, to be preferred over government indifference. Moreover, many UK government responses reflect a feminist and communityinformed understanding that forced marriage is a harm that is based upon power imbalances concerning gender and sexuality rather than simply being a reflection of 'culture'. The Forced Marriage Unit information brochure for lesbians and gay men states:

A forced marriage is conducted without the consent of one or both people, and pressure or abuse is used. This could include both physical pressure (when someone threatens to or actually does hurt you) or emotional pressure (for example, when someone tries to make you feel that your sexuality brings shame on your family) to get married. ${ }^{50}$

Given the pace and diversity of engagement in forced marriage issues in the United Kingdom, we anticipated that decision makers would have an increasingly well informed understanding of forced marriage as a gendered human rights abuse. Indeed in the 2002 wardship case Re $M$ the court spoke of the often 'irrevocable step' for those escaping forced

\footnotetext{
${ }^{48}$ Home Office, UK Border Agency, 'Annex A2 - Guidance and Instruction on Forced Marriage' (2009). For the reasoning behind this measure see: Home Office, UK Border Agency, Marriage Visas: The Way Forward (July 2008).

${ }^{49}$ Marriage Visas, ibid, at [5.1]-[6.15]. In addition the paper sets out a 'medium term goal' of introducing a preentry English test for marriage applicants in order to promote 'integration'.

${ }^{50} \mathrm{FMU}$, 'Guide to Forced Marriage for LGBT People' (c 2007), 2.
} 
marriage in terms of familial abuse and social exclusion, and urged government entities to assist by 'offering effective exit' ${ }^{51}$

Courts and local and education authorities primarily, but also public authorities generally should recognise that their needs must be urgently and effectively met. ${ }^{52}$

Yet we found the refugee cases, in particular those decided by English courts and tribunals, were utterly at odds with these domestic developments. This is not to suggest that refugee case law should or could respond in precisely the same way as the domestic legal framework does. Rather, given refugee law's role as surrogate or 'back up' human rights protection, we would hope to find refugee law taking forced marriage seriously, viewing it as a gendered practice, and analysing it in ways that are commensurate with human rights infused domestic initiatives. This was simply not so.

\section{THE REFUGEE CASES}

The cases examined for this research comprise all the tribunal and court refugee determinations available in English from 1995 to 2008 (inclusive) in three countries where forced marriage appeared as part of the claim. ${ }^{53}$ There were 120 decisions in total, made up

\footnotetext{
${ }^{51}$ Re M Minors [2002] EWHC 852 at [25]-[26].

${ }^{52}$ ibid at [26].

${ }^{53}$ Australian cases were all obtained from the Austlii case database (www.austlii.edu.au). UK cases were obtained from the Electronic Immigration Network case database (www.ein.org.uk), the Asylum and Immigration Tribunal website (www.ait.gov.uk), LEXIS and UN RefWorld databases. Canadian cases were obtained from the QuickLaw, Canlii (www.canlii.org) and LEXIS databases. The search terms used were 'forced marriage' 'forced to marry' and 'pressure to marry'. Cases cover the period from January 1995 to December 2008. There were no New Zealand cases identified. In Australia and the UK the original decision on refugee status is taken by a delegate of the Minister, who is a bureaucratic officer. If this determination is negative, the applicant can apply for a de novo merits review of the decision. In Australia this review is undertaken by the Refugee Review Tribunal (RRT) which sits with a single member. In the UK until April 2005 this review was undertaken by the Immigration Appellate Authority (IAA) in a two tier system: first, an immigration adjudicator reviewed the decision de novo and then leave could be given to the Immigration Appeal Tribunal (IAT) which until 2002 provided a second level of de novo review and after 2002 was limited to points of law by the Nationality, Immigration and Asylum Act 2002 (UK). From 2005 the two-tier structure was abolished and replaced by the Asylum and Immigration Tribunal (AIT): Asylum and Immigration (Treatment of Claimants, etc) Act 2004 (UK). The AIT can only grant review based on an error of law. Canada is unique in that the Tribunal makes the first determination. Until 2002 this body was the Convention Refugee Determination Division which sat in two member panels, with a difference between the members resulting in a positive determination. Since 2002 the new Refugee Protection Division (RPD) sits with only one member. There is no comparable release of low level US cases. Our analysis of the available US cases appears in another paper, see $\mathrm{n} 1$ above.
} 
of 69 decisions from Australia, 40 from Canada and a mere 11 from the UK. ${ }^{54}$ This set includes all judicial level decisions, but may represent as few as 5-10 per cent of those made by the low level administrative tribunals because of limited release of such cases. While the small proportion of tribunal level cases raises the possibility that they could be unrepresentative of decisions at that level more generally, they nonetheless offer the best available data. Moreover, the fact that most of the trends we identified occurred at both tribunal and judicial level suggest that the available tribunal cases were not atypical overall.

Given the prominence of UK domestic initiatives on forced marriage the very low number of UK cases is extraordinary, even taking into account the low release rate of tribunal decisions in that jurisdiction. It is impossible to understand the reasons for this with any certainty, but it is plausible that UK legislation which presumptively treats applications from a list of countries (known as the 'white list') ${ }^{55}$ as unfounded has had considerable impact in reducing the likelihood of forced marriage claims being adjudicated, especially at higher levels. Applicants from 'white list' countries with negative determinations are 'certified' so that a right of appeal from original bureaucratic level decisions is operative only from outside the UK. In addition 'fast track' adjudication at first instance has been particularly problematic in gender claims, and claimants from 'safe' or white list countries are far more likely to be subject to fast track processes. ${ }^{56}$ UK domestic initiatives concerning forced marriage have focused heavily, although not exclusively, on communities from Pakistan, Bangladesh and, to a lesser degree, India and Sri Lanka; yet none of these countries of origin appear in the ten available UK cases. While the original 2002 white list addressed EU accession countries, further countries were added in subsequent years: Sri Lanka and Bangladesh were added in 2003 (although Bangladesh was removed again in April 2005 and Sri Lanka removed in December 2006), while India was added in February $2005 .{ }^{57}$

\footnotetext{
${ }^{54}$ Australian cases comprised 54 tribunal decisions and 15 Federal Court decisions, Canadian cases comprised 13 tribunal decisions and 27 decisions of the Federal Court, UK cases comprised six tribunal decisions and five decisions of the Court of Appeal.

${ }^{55}$ Nationality, Immigration and Asylum Act 2002 (UK), s 94.

${ }^{56}$ See eg, Asylum Aid, 'Submission of Evidence to the Independent Asylum Commission' (July 2007); UNHCR London, Quality Initiative Project: Key Observations and Recommendations 2007-2008 (2008).

${ }^{57}$ UK Home Office, Asylum Policy Instruction, 'Certification under Section 94 of the NIA Act 2002' (August 2006).
} 
Across the whole pool, the most common countries from which claims arose were Bangladesh, Nigeria, India, Indonesia, Iran and Ghana, although only Bangladesh and Nigeria gave rise to more than 10 claims each. ${ }^{58}$ In fact the range of countries of origin was vast and unpredictable, coming from 39 separate countries, while claims from only 10 countries of origin - Bangladesh, China, Ghana, Iran, Jordan, Kenya, Lebanon, Nigeria, Uganda and Turkey - were made in more than one of the three receiving states.

Women claimants outnumbered men exactly two to one. However gender alone gives an incomplete picture as sexuality was a very significant factor; women's cases were largely heterosexual while men's claims were almost exclusively gay. Of the 80 decisions involving women, 10 were lesbians while the remaining 70 were women identified as, or assumed by decision-makers to be, heterosexual. Of the 40 decisions involving men, 38 were gay, while only 2 were heterosexual. Looking at the cases by sexual orientation thus reveals a 60 per cent heterosexual and 40 per cent homosexual divide. ${ }^{59}$

Success and failure rates of claims, while drawn from what is only a partial case set, and based upon small numbers of claims, provide some important clues. The overall positive rate in decisions was 32 per cent. ${ }^{60}$ Within the umbrella of 'forced marriage' we identified distinct categories of claim: those where a marriage had actually taken place ('actual forced marriage') and those where a forced marriage had not yet taken place ('threatened

\footnotetext{
${ }^{58} 21$ claims were from Bangladesh, 12 from Nigeria, 6 from China, Ghana, India and Indonesia, 5 from Iran and Lebanon, 4 claims from Kenya and Zimbabwe; 3 claims from Egypt, Fiji, Nepal, the Philippines and Uganda; 2 from Ethiopia, Guinea, Jordan, Mali, Turkey and Zambia. There was 1 claim from each of the following countries: Afghanistan, Albania, Burkina Faso, Central African Republic, Chad, Democratic Republic of Congo, Ecuador, Liberia, Malaysia, Morocco, Pakistan, Saudi Arabia, South Africa, Sierra Leone, Sudan, Syria, Ukraine, and Vietnam.

${ }^{59}$ Of the total pool there were: heterosexual women 58 per cent, gay men 32 per cent, lesbians 8 per cent and heterosexual men 2 per cent.

${ }^{60}$ The study counted 'positive' or 'negative' decisions from the perspective of the applicant, even if (as in the case of judicial review and also some UK Tribunal outcomes) the decision involves remittal and reconsideration of the claim rather than a substantive positive determination of refugee status. This gives an inflated sense of 'positive' outcomes, as we do not have access to the majority of the remittal determinations and some, perhaps many, of these will ultimately be negative to the applicant. These figures also mask significant divergence across the receiving nations: with the positive rate 43 per cent in Canada and 26 per cent in Australia. In the UK of only 11 decisions, three were positive, but two of these were in fact remittals.
} 
marriage'). Within 'threatened marriage' there was a further difference between claims which involved a specific threat of marriage to a particular individual and those which rested on a more general pressure or coercion to marry. ${ }^{61}$

There were clear differences across these categories both in terms of the representation of heterosexual women versus gay men, and in comparative rates of success. Not surprisingly, 'actual forced marriage' cases displayed a higher positive rate than 'threatened marriage' (44 per cent compared to 28 per cent). 'Actual forced marriage' claims comprised mostly heterosexual women. ${ }^{62}$ Among 'threatened marriage' specific threats of marriage also overwhelmingly concerned heterosexual women ${ }^{63}$ whereas claims of a more general pressure to marry were more likely to involve gay men. ${ }^{64}$ Marriage itself was usually the central feature of heterosexual women's claims, whereas it was often a more minor or cumulative part of claims brought by gay men. The lesbian cases were exactly divided, with half of them featuring actual forced marriage or a specific threat such that forced marriage was central to the claim in a manner akin to the heterosexual women's cases, while the other half were more similar to the gay men's claims in that homophobically motivated persecution was the core element of a claim in which marriage was a general threat or more tangential aspect. Notably, gay men were markedly more successful than heterosexual women overall (40 per cent positive compared to 27 per cent), while lesbians fell in between the two (30 per cent positive). ${ }^{65}$ The reasons for these differences are explored below.

Claimants must demonstrate that the risk they face is 'for reasons of' one of the articulated grounds for protection: race, religion, nationality, political opinion or membership in a

\footnotetext{
${ }^{61}$ Sixteen decisions concerned an actual forced marriage, while marriage was threatened in 104 of the decisions (comprising 63 where the threat was specific and 41 where the threat was general).

6212 heterosexual women, 2 gay men and 2 lesbians. Six of the heterosexual women and one of the gay male claims in this category were positive, but neither of the lesbian claims succeeded.

${ }^{63} 48$ of the 63 decisions were heterosexual women, with 10 gay men, 3 lesbians and 2 heterosexual men. One heterosexual man and one lesbian in this group were successful.

${ }^{64}$ Of 41 decisions on general pressure, gay men compromised 26, with 10 heterosexual women, and 5 lesbians.

${ }^{65}$ Bearing in mind that there were only 10 lesbian cases, so even one additional positive or negative decision would tilt these figures significantly. Of the two claims made by heterosexual men one was negative and the other positive.
} 
particular social group. In forced marriage cases, the nexus which is usually argued is to membership of a particular social group such as 'gay men', 'lesbians', 'homosexuals' or 'women'. Both gender and sexual orientation claims are grounded in an individual's nonconformity with prevailing social and religious codes concerning gender roles, sexual behaviour and accepted modes of family formation. UNHCR gender guidelines released in 2002 acknowledge this common underpinning, noting that sexual orientation claims 'contain a gender element' because of refusal to 'adhere to socially or culturally defined roles or expectations of behaviour attributed to his or her sex'.66 The experience of direct persecution by state agents is rare in both gender and sexuality claims which much more commonly concern harm at the hands of non-state actors, often of an on-going rather than one-off nature, and failure of effective state protection. All groups of applicants examined in this research struggled to articulate the harm of forced marriage and to establish a nexus between their convention ground and the harm feared. However the issue of identifying the social group was particularly difficult for heterosexual women, whereas for gay men and lesbians establishing the nexus between the group and the persecution, that is, that the harm feared was 'for reasons of' their group membership, posed the major barrier. A further persistent issue for all claimants is that they must be found to be credible: their story must be believed.

\section{Particular social group}

While Canada accepted gender-based grounds for refugee claims, including forced marriage, from the mid-1990s, gender was not widely accepted in Australian jurisprudence as the basis for a particular social group prior to the High Court decision in Khawar in $2000^{67}$ and was likewise only accepted in the UK following the House of Lords' 1999 decision in Shah and Islam. $^{68}$

\footnotetext{
${ }^{66} \mathrm{n} 14$ above at [16].

${ }^{67}$ Minister for Immigration and Multicultural Affairs v Khawar (2002) 210 CLR 1.

${ }^{68} R$ v IAT \& Secretary of State for the Home Department ex parte Shah; Islam v IAT ('Shah and Islam') [1999] 2 AC 629.
} 
Many claims brought by heterosexual women in Australia in the 1990s failed because the decision-maker was not prepared to accept that 'women' ${ }^{69}$ or women 'defying their parents' marriage arrangements' were capable of forming a social group. For example:

It may be the case that there are many people who defy their parents regarding marriage arrangements, but this does not lead to them being recognisable as a particular social group, notwithstanding that they have in common their acts of defiance. In this case, the harm feared by the Applicant is a consequence of what she has done, not what she is. ${ }^{70}$

In cases such as this one the failure to accept a social group led to rejection of a claim even though the threshold for a well-founded fear of persecution had actually been met. ${ }^{71}$ These difficulties in establishing a social group definition go some way towards explaining the relative success of gay and lesbian claims when compared to those of heterosexual women (in particular when it is recalled that Australian decisions comprise a large portion of the pool. ${ }^{72}$ )

In the UK it was striking that, even after Shah, cases through the early to mid 2000s continued to hold that there was no applicable social group for women fleeing forced marriage. On two occasions where first instance Adjudicators did find a social group in the course of making a positive decision, the government appealed the decision and contradicted its own gender guidelines by specifically arguing that findings of a social group were an error of law. ${ }^{73}$ The sole UK case to contain a rights oriented analysis of forced

\footnotetext{
${ }^{69}$ V96/04454 [1996] RRTA 1436 (6 June 1996) (China).

${ }^{70}$ V94/01794 [1995] RRTA 403 (28 February 1995)(Turkey), 8. See also V96/04454 [1996] RRTA 1436 (6 June 1996) (Indonesia); N97/15435 [1998] RRTA 429 (28 January 1998) (Ecuador); N97/14105 [1998] RRTA 2531 (12 May 1998)(Nigeria); N98/25482 [1999] RRTA 1978 (16 November 1999) and N95/09554 [1996] RRTA 340 (22 February 1996)(Syria) where the applicant's advisor did not put forward a Convention ground and the Tribunal held that there was not one.

${ }^{71}$ See also the finding that the applicant could face harm from the government in China based upon her departure, but as her departure was not politically motivated this was unlikely and would not be relevant in any case as the applicant did not flee for a Convention reason, but on account of a claimed forced marriage': v96/04454 [1996] RRTA 1436 (6 June 1996) (China), 10.

${ }^{72}$ Heterosexual women had a positive rate of only 11 per cent in Australia prior to Khawar, n 67 above, and a 38 per cent positive rate subsequently.

${ }^{73}$ See YK (PSG-Women) Turkey CG [2002] UKIAT 05491 (28 November 2002) in which the Tribunal granted an appeal, overturning the finding that 'women in Turkey' comprised a social group. See also RG (Ethiopia) $v$ Secretary of State for the Home Department [2006] EWCA Civ 339. See IAT Gender Guidelines n 12 above and UK Home Office Asylum Policy Instructions, n 13 above.
} 
marriage arrived at the Immigration Appeal Tribunal in 2004 in part because of a failure at first instance to find that women in Afghanistan, or some subset thereof, could be considered a social group. ${ }^{74}$ Yet such failures continued; in 2005 the Immigration Appeals Tribunal held that fleeing both forced marriage and female genital mutilation (FGM) engaged neither the political nor religious grounds of the Convention and that 'Nothing we have heard persuades [us] that the appellant can bring herself within a [social] group' ${ }^{75}$ In that case the Tribunal appeared to consider that the forced marriage was entirely a familial dispute with no wider social relevance.

The UK approach was in stark contrast to Canada, where no claim by a female applicant in our pool was rejected on the basis that she lacked a Convention ground. In the Canadian cases, the particular social group was framed variously as 'women', ${ }^{76}$ 'women who refuse to follow traditional practices'77, 'women subject to forced levirate marriage'78, 'women being forced to marry against their wishes" ${ }^{79}$ and 'women regarded as chattels' ${ }^{80}$ On occasion no formulation of the social group at all appeared in the reasons for Canadian determinations. ${ }^{81}$ In Australia, post-Khawar, the group used likewise ranged from broad ('women's2) to narrow

\footnotetext{
${ }^{74}$ NS (Afghanistan) CG [2004] UKAIT 00328.

${ }^{75}$ See eg JM (Kenya) [2005] UKIAT 00050 (22 February 2005) at [35]. Note that in Fornah v SSHD [2006] UKHL 46 the House of Lords subsequently held unanimously that a young woman from Sierra Leone at risk of FGM was a member of a PSG (although there was disagreement as to breadth of the PSG: 'women' or 'uninitiated' women). Baroness Hale memorably began her speech by noting that, 'The answer in each case is so blindingly obvious that it must be a mystery to some why either of them had to reach this House' at [83].

${ }^{76}$ X v Canada (Immigration and Refugee Board) [2001] CanLII 26862 (IRB) (26 November 2001)(Central African Republic).

${ }^{77} \operatorname{Re} X$ [2002] CanLII 52705 (IRB) (9 September 2002)(Zimbabwe), 3.

${ }^{78} \operatorname{Re} X$ [2002] CanLII 52707 (IRB) (13 November 2002)(Nigeria).

${ }^{79} \operatorname{Re} X$ [2006] CanLII 61633 (IRB) (27 March 2006)(Zimbabwe).

${ }^{80}$ This was the Tribunal's own formulation: $\operatorname{Re} X$ [2000] CanLII 21420 (IRB) (10 January 2000)(Zambia), 3.

${ }^{81}$ See eg Re X [2000] CanLII 21442 (IRB) (11 July 2000)(Nigeria); Re X [2001] CanLII 26821 (IRB) (6 February 2001)(Lebanon).

${ }^{82} 071426303$ [2007] RRTA 132 (29 June 2007)(Saudi Arabia).
} 
('women in Northern Albania who have failed to honour an arranged marriage' ${ }^{83}$ ) with no clear correlation between the specificity of the group and the rate of success.

While the domestic refugee jurisprudence of all three countries has held that a particular social group cannot be solely defined by reference to the persecution (so for example, a group formulated as 'women in Iran who are forced by their fathers to marry' is unacceptable) it is clear from the forgoing discussion that Canada has taken a less strict approach to this issue than the UK or Australia. ${ }^{84}$ In 2005, after an exhaustive review of the case law on particular social group and gender, the UK Immigration Appeal Tribunal noted 'from experience that such cases often appear to became bogged down in pedantic, and often unnecessary, argument as to definition of the particular social group'. ${ }^{85}$ In that case the Tribunal took the unusual step of itself formulating the group ('Young Iranian Women who refuse to enter into arranged marriages'), holding that this group was defined by its non-conformity rather than the persecutory outcome which followed, and thus presented an acceptable basis for the particular social group. ${ }^{86}$ Thus resistance or opposition to the persecution (which is surely implicit in the making of the refugee claim) rather than the experience of the persecution is centred as the requisite basis of group membership. ${ }^{87}$ Ironically, this represents a belated acceptance of the position first put by UNHCR in $1985{ }^{88}$ and restated over and over since then in various gender guidelines, that the basis of many women's claim to a particular social group will be their non-conformity with prevailing social mores.

\footnotetext{
${ }^{83}$ V0618399 [2006] RRTA 95 (22 June 2006)(Albania).

${ }^{84}$ See eg TB (Iran) [2005] UKIAT 00065 (9 March 2005) at [56]-[57]; N97/14882 [1998] RRTA 1005 (25 February 1998)(Lebanon), 8.

${ }^{85}$ TB (Iran) [2005] UKIAT 00065 (9 March 2005) at [66].

${ }^{86}$ TB (Iran) [2005] UKIAT 00065 (9 March 2005) at [57].

${ }^{87}$ For an early critique of this position on the basis that it undermines the status based nature of the particular social group ground see L. Rosenberg, concurring opinion in Re Kasinga [1996] BIA LEXIS 15 (13 June 1996).

${ }^{88}$ UNHCR Ex-Com, $36^{\text {th }}$ Session, No 39 (1985) cited in K. Musalo, 'Revisiting Social Group and Nexus in Gender Asylum Claims: A Unifying Rationale for Evolving Jurisprudence’ (2003) 52 DePaul Law Review 777.
} 
In terms of the sluggishness of UK and Australian developments in gendered refugee jurisprudence, it is also interesting to note that even when the UK tribunal accepted in 2008 that a woman opposing FGM and forced marriage was eligible based on 'resistance to accepting the prevailing cultural norms in her own rural society', it did so largely by reference to FGM with very little engagement with the issue of marriage; moreover it expressly denied that this kind of resistance could be characterised as political opinion or imputed political opinion. ${ }^{89}$ Australian decision-makers have also repeatedly resisted any notion that forced marriage engages any other Convention ground apart from social group. ${ }^{90}$ In contrast Canada decision-makers frequently characterised forced marriage claims as engaging both particular social group and the religious or political ground under the Convention.

Gay claimants did occasionally fail to be accepted as a social group, particularly if forced marriage was a significant part of their claim. For example in the 1998 Australian Federal Court decision of $M M M$, the court collapsed gay men facing pressure to marry with 'bachelors', making the social group both trivial and nebulous:

These would, no doubt, include, for example, widowers, men keen to marry, misogynists, homosexuals, fathers and non-fathers, rich men and poor, devout Muslims and others, handsome men and ugly, those already engaged to be married and those not. ${ }^{91}$

While gay men and lesbians were more likely to be accepted as forming a particular social group than heterosexual women because their group was seen as more finite and also as cognisable beyond the context of marriage as the harm feared, it was conversely harder for

\footnotetext{
${ }^{89}$ FB (Sierra Leone) [2008] UKAIT 00090 'The appellant, of course, holds no political opinions. She does not approve of FGM or wish to participate in the Bondo or to marry an elderly man occupying a position of local chief. Her motives are not political in any discernible way' at [72] (emphasis in original). In considering that the prospective groom was a major local political figure the Tribunal responded that there was 'but a peripheral connection between these political strands' and 'her obvious reluctance to marry a man for whom she does not care' at [73].

${ }^{90}$ See eg N95/06944 [1996] RRTA 3480 (4 December 1996)(Bangladesh). One exception was in a case where the forced marriage meant that the woman would have to convert to Islam: N98/25465 [2001] RRTA 27 (12 January 2001)(Ghana).

${ }^{91}$ MMM v Minister for Immigration \& Multicultural Affairs (1998) 90 FCR 324 (Bangladesh) at [4].
} 
them to establish that persecution relating to forced marriage was therefore 'for reasons of' their group membership.

\section{Nexus: marriage and sexuality as unrelated things, marriage as universal}

Marriage was often understood by decision-makers as a 'general' or 'universal' expectation such that they frequently did not see any nexus between claims of forced marriage and sexual orientation, even when the marriage itself or conduct associated with it was accepted as persecutory. ${ }^{92}$ This also occurred, although to a far lesser extent, in claims made by heterosexual women where decision-makers accepted a social group based on gender but characterised pressure to marry as 'universal' because it affected men also, or as entirely personal, social or 'cultural'. ${ }^{93}$ It appears that the characterisation of claims under the particular social group membership ground rather than political or religious grounds may impede the ability to find a nexus because this reinforces the underlying notion that what is at stake is fundamentally a social or cultural matter. ${ }^{94}$ For example:

there is a social pressure for both males and females to marry and that the extent of that pressure varies amount [sic] different social groups. The Tribunal acknowledges that the motivation to marry is based on cultural reasons rather than any Convention related motivation. ${ }^{95}$ (emphasis added)

In addition, many decision-makers simply saw no connection at all between forced marriage and homosexuality. For example in a 1998 Australian case:

The evidence is that all adult males in Bangladesh are subject to pressure to marry and form a family. The applicant's claims about pressure to marry do not arise by reason of his membership of a particular social group of homosexual men in Bangladesh. ${ }^{96}$

\footnotetext{
${ }^{92}$ See eg N02/44482 [2003] RRTA 1076 (10 November 2003); N99/28400 [2001] RRTA 846 (26 September 2001) at [10]; V97/06971 [1999] RRTA 260 (1 February 1999).

${ }^{93}$ N98/22760 [2001] RRTA 532 (8 June 2001)(Lebanon).

${ }^{94}$ See eg N02/44482 [2003] RRTA 1076 (10 November 2003) (Egypt). For an overview of nexus and gender related claims see Musalo, n 88 above.

95 SZATS v MIMIA [2004] FMCA 660 (11 November 2004) (Nepal) paraphrasing the findings of the Tribunal at [52].

96 N94/04854 [1998] RRTA 3506 (21 July 1998), 28. Repeated verbatim: N95/09552 [1998] RRTA 4153 (4 September 1998), 19-20.
} 
In a 1999 case the Australian Tribunal added that while forced marriage 'is regrettable and potentially a breach of human rights' it is not 'for reasons of membership of a particular social group of homosexuals in Pakistan' because while it 'certainly has the potential to adversely affect homosexual people... it also has the potential to affect other people who do not wish to marry at all, or who do not wish to marry at a particular time, or a particular person. ${ }^{97}$ At times decision-makers expressly held that pressure to marry would be "no more harmful than the social pressure upon a heterosexual man or woman to marry against their will' 98

This 'universalising' impulse produced two results: an implicit exclusion of the prospect that the forced marriage of heterosexual women and men is also Convention persecution, and second a failure to acknowledge that gay men and lesbians are not similarly situated in relation to marriage in comparison with heterosexual people for the very reason that marriage is a heterosexual institution. Far from being a 'social convention of general application' $^{\prime 99}$ marriage is, rather, a heterosexual convention with unequal application and impact.

In Australia a long line of cases debated the question whether pressure to marry exerted a 'differential impact' on gay men and lesbians. In the 1998 decision of MMM the Federal Court held that although the impact of forced marriage would be different (it may 'fall harder' on 'an unwilling homosexual than an unwilling heterosexual') the treatment itself was not 'applied differentially' and so was not 'for reasons of'. ${ }^{100}$ While other decisions have not necessarily agreed with this approach, it was expressly endorsed by the Full Federal

\footnotetext{
${ }^{97}$ V97/06971 [1999] RRTA 260 (1 February 1999)(Pakistan), 22-23.

${ }^{98}$ SZAOD v MIMIA [2004] FMCA 89 (19 March 2004)(Bangladesh) at [16] quoting the Tribunal.

${ }^{99}$ ibid at [19].

${ }^{100}$ MMM v MIMIA (1998) 90 FCR 324 (Bangladesh). For critiques of the decision see: R. Germov and F. Motta, Refugee Law in Australia (Melbourne: Oxford University Press, 2003), 327; J. Millbank, 'The Role of Rights in Asylum Claims on the Basis of Sexual Orientation' (2004) 4 Human Rights Law Review 193.
} 
Court in 2005 which held that there was no 'singling out' of gay men in the context of pressure to marry. ${ }^{101}$

\section{Persecution}

A major gender difference, of significance in all of the receiving countries, was the role that forced marriage played. While marriage itself was almost always a significant, or critical, aspect of the claimed harm in women's cases, it appeared rather as a catalyst for the harm feared in gay men's cases. That is, in gay men's claims, refusal to marry was commonly articulated as something that would in time publically indentify the applicants as gay because they lived in a cultural setting where marriage was regarded as compulsory and inevitable. ${ }^{102}$ Alternately, gay claimants on occasion argued that submitting to marriage would expose them as gay because wives would realise or suspect their sexuality. ${ }^{103}$ The inability of decision-makers to view an unwanted heterosexual marriage as in and of itself harmful to a gay man is starkly highlighted by an early Australian case where the decisionmaker actually suggested to the gay male applicant 'living a secret gay life and perhaps even marrying' as a means to ensure a future safe from persecution. ${ }^{104}$ While it is rare to see this view put so openly, it clearly forms the basis of assumptions about safety for gay and lesbian applicants in numerous other decisions where tribunals find that applicants can be 'privately gay' alongside uncontested country of origin information that 'marriage is considered a social necessity'. ${ }^{105}$

In women's cases, marriage itself was often framed as the dominant basis of the claim. Yet, although an unwanted marriage constituted a significant part of the harm feared by women, and was often articulated as the main basis of the claim, it was infrequently received as

\footnotetext{
${ }^{101}$ MIMA v SZANS (2005) 141 FCR 586 (Bangladesh) at [41]-[42].

102 This was sometimes accepted as grounding a well founded fear: see eg N98/21330 [1999] RRTA 1890 (20 October 1999)(India); N04/49626 [2005] RRTA 6 (23 March 2005)(Bangladesh).

${ }^{103}$ Such claims were rarely accepted. See eg: N99/28449 [2002] RRTA 1125 (17 December 2002)(Bangladesh); ignoring this risk was characterised as an error by the Magistrate in SZANS v MIMIA (2004) 186 FLR 158 but was overturned on appeal by the Full Federal Court as beyond jurisdiction in MIMA v SZANS (2005) 141 FCR 586.

${ }^{104}$ N97/14489 [1998] RRTA 3545 (23 July 1998)(Nepal).

${ }^{105}$ N98/23844 [2000] RRTA 842 (29 August 2000)(India).
} 
such. Instead, decision-makers addressed either the persecutory consequences of refusing to marry, or of leaving a forced marriage, for women, resulting in a complete absence of discussion of the persecutory nature of an imposed marriage itself. ${ }^{106}$ Indeed in a 2008 UK decision, issued after the new Forced Marriage Act was introduced to much public fanfare, the Asylum and Immigration Tribunal, hearing an appeal on a point of law from a government adjudicator, held that, 'It is unnecessary to determine whether a forced marriage is, in all cases, itself persecutory treatment. ${ }^{107}$

In both heterosexual and gay and lesbian claims, the harm feared was often construed as social, familial and privately motivated when family members were the agents of persecution, with little or no consideration of the willingness or ability of the state to protect applicants from such harm. ${ }^{108} \mathrm{~A}$ notable example concerns a gay man beaten by several family members, where the Australian Tribunal responded:

Such tragic family rows happen all the time anywhere, for a variety of reasons: someone does not want to marry a chosen partner; someone marries an "undesirable" person; someone brings scandal on the family through drunkenness or drug-taking or gambling or having illicit affairs; someone has disappointed the family by not passing an examination. ${ }^{109}$

The first two examples on this list would be regarded as paradigm examples of forced marriage harms under the UK's domestic FMU approach. ${ }^{110}$ Yet here the decision-maker implicitly characterises both being gay and refusing to conform to pressured or coerced marriages as 'disappointing' or 'scandalous' personal failings rather than as matters key to human rights and human dignity.

\footnotetext{
$\overline{106}$ See eg N95/06944 [1996] RRTA 3480 (4 December 1996)(Bangladesh); Brahmbhatt v MIMA [2000] FCA 1686 (22 November 2000)(India).

${ }^{107}$ FB (Sierra Leone) [2008] UKAIT 00090 at [54].

108 See eg N97/15435 [1998] RRTA 429 (28 January 1998)(Ecuador) where harm from family is 'personal', 16 and 'individual', 17.

${ }^{109}$ N98/21362 [2002] RRTA 282 (28 March 2002)(India/Bangladesh), 7.

${ }^{110}$ See eg FMU 'Young People and Vulnerable Adults Facing Forced Marriage: Practical Guidance for Social Workers' (2004), 2.
} 
A second prevalent theme in the refugee cases, which also contrasted starkly with the domestic approach to forced marriage, was the focus on physical violence to the exclusion of consideration of emotional and environmental pressure, or to diffuse but threatening behaviours such as ostracism or deprivation of sources of economic support. ${ }^{111}$ Refugee decision-makers focused quite literally upon 'force' rather than related questions of coercion, duress or ability to meaningfully consent in the circumstances of the case. Yet domestic law in the receiving nations under discussion has dealt with the issue of nonconsensual or forced marriage over many decades. Applications for nullity of marriage on the grounds of duress have considered in detail what 'free consent' to marriage means through examination of motivations and events leading up to and including the marriage itself. Broadly speaking, in determining whether the applicant's will was 'overborne', there has been a clear move away from a narrow approach to duress requiring threats or acts of physical violence and fear of immediate danger, ${ }^{112}$ to instead take into account a wider range of psychological pressures, emotional threats, abuse and manipulation as well as the broader family and social context in which the engagement and marriage took place in order to determine whether there was genuine consent or only reluctant submission to the marriage. ${ }^{113}$ Such an approach is reflected in the materials of the FMU. Yet refugee cases rarely, if ever, engage with the idea of an applicant's free will, and virtually all of them dismiss out of hand the idea that continued psychological pressure or threats from family members unaccompanied by physical violence is sufficient to constitute 'force' in 'forced marriage'.

Instead, in the refugee decisions, lack of social or legal power and the ability to consent particularly for women applicants - appears to be represented through the blunt proxies of education, age, urbanity and 'independence' (itself represented by the proxies of income and unaccompanied travel). It was particularly notable that the education level of women

\footnotetext{
${ }^{111}$ For an exception, see $\operatorname{Re} X$ [2002] CanLII 52705 (IRB) (9 September 2002)(Zimbabwe).

${ }^{112}$ See eg Singh v Kaur (1981) 11 Fam Law 152; Parihar v Bhatti (1980) 17 RFL (2d) 289; Kecskemethy v Magyar (1961) 2 FLR 437.

${ }^{113}$ See eg In the Marriage of S [1980] FLC 90-820; Hirani v Hirani [1983] 4 FLR 232; P v R [2003] 1 FLR 661; NS v MI [2007] 1 FLR 444; Re S [2007] 2 FLR 461; Mahmud v Mahmud [1994] SLT 599; Sohrab v Khan [2002] SCLR 663.
} 
(and/or their sisters) was subject to close scrutiny in assessing whether they were at risk of forced marriage, whereas the education level of men claiming forced or pressured marriage was rarely mentioned and was never relevant to the determination.

Being 'highly' educated (usually taken to mean completion of secondary education), over the usual marriageable age for the country of origin, residing in an urban rather than a rural area, or exhibiting 'independence' through being employed or having travelled without parental supervision, were frequently taken to mean that female applicants did not 'fit the profile' for forced marriage. This was taken as proof that they were not 'disempowered' and were therefore able to refuse marriage (and were also capable of relocating away from any persecution or seeking state protection). ${ }^{114}$ So, for example in a 2001 Canadian case, country evidence that urban and highly educated women in Lebanon were 'somewhat less constrained' by social customs and faced 'less severe consequences' for non-conformity than those who were less educated and lived in rural areas was re-interpreted by the decision-maker as 'objective evidence' that the claimant 'would not be subject to forced marriage, and if she were, could evade it. ${ }^{115}$

\section{Credibility: who families are and how they behave}

While in general decisions from Canada were more sophisticated than the UK and Australia in their approach to all of the issues explored above, Canada was notable for some very

\footnotetext{
${ }^{114}$ See eg the following negative cases: Re X [2001] CanLII 26821 (IRB) (6 February 2001) (Zimbabwe)(educated, urban); Re X [2006] CanLII 61633 (IRB) (27 March 2006) (Zimbabwe)(educated); Re X [2001] CanLII 26821 (IRB) (6 February 2001)(Lebanon) (urban); Afriyie $v$ Canada (Minister of Citizenship and Immigration) [2003] FCT 802 (27 June 2003)(Ghana)(sophisticated, well-educated, urban); Adams v Canada (Minister of Citizenship and Immigration) [2003] FCT 386 (1 April 2003)(Nigeria)(age, education, urban); N99/29824 [2001] RRTA 890 (16 October 2001)(India)(well-educated, empowered); V97/05699 [1997] RRTA 2735 (21 July 1997)(Iran)(education, allowed to travel); V97/06802 [1997] RRTA 3846 (30 September 1997)(China)(age); N02/44026 [2003] RRTA 521 (6 June 2003)(Lebanon)(educated, allowed to travel). See further first instance decisions referenced, but overturned, in the following judicial review decisions: Eimani $v$ Canada (Minister of Citizenship and Immigration) [2005] FC 42 (17 January 2005)(Uganda) referring to findings of the Tribunal that she 'did not fit the profile of the typical victim of arranged marriage' because she was urban, educated and travelled at [6]; Gill $v$ Canada (Minister of Citizenship and Immigration) [2004] FC 902 (23 June 2004)(Zimbabwe) referring to earlier findings of Tribunal that it was not plausible the father would force marriage as the family was 'educated and urban' quoted at [9]; and Vidhani v Canada (Minister of Citizenship and Immigration) (TD) [1995] CanLII 3606 (FC) (8 June 1995)(Kenya) concerning a 25 year old 'in a business career since the age of 18 ' with 'money of her own'.

${ }^{115} \operatorname{Re} X$ [2001] CanLII 26821 (IRB) (6 February 2001)(Lebanon), 4.
} 
problematic first instance decisions on credibility (although some of these were later disapproved of on judicial review). In particular, credibility determinations in forced marriage claims revealed a range of largely unsupportable 'plausibility' assumptions ${ }^{116}$ about what marriage is and how families behave.

Canadian tribunal members held that forced marriage claims were false on the basis that the following aspects of claims were inherently 'implausible':

- a Christian father in Kenya arranged a forced marriage for his only daughter 'with a considerably older man with multiple wives', (likewise a Christian father in Nigeria); ${ }^{117}$

- a Christian groom engaged in polygamy; ${ }^{118}$

- family members opposed to a forced marriage did not approach state authorities in Zimbabwe; ${ }^{119}$

- a mother concerned about the forced marriage of her daughter left her 'near' the father; ${ }^{120}$

- a 'determined and aggressive' young woman in Guinea was nevertheless forced to marry; ${ }^{121}$

- an 18 year old Chinese girl who was a 'family victim or exploitee', still telephoned her parents subsequent to a refugee claim and claimed to love them; ${ }^{122}$ and

\footnotetext{
${ }^{116}$ See also J. Millbank 'The "Ring of Truth": A Case Study of Credibility Assessment in Particular Social Group Refugee Determinations' (2009) 21 International Journal of Refugee Law 1.

${ }^{117}$ Referenced in Gill v Canada (Minister of Citizenship and Immigration) [2004] FC 902 (23 June 2004) at [9] which overturned the decision on judicial review. See also the Tribunal finding that a Christian family would not force a daughter into a polygamous marriage referred to in Otti $v$ Canada (Minister of Citizenship and Immigration) [2006] FC 1031 (28 August 2006) which overturned it on judicial review.

${ }^{118}$ Referred to in Gill v Canada (Minister of Citizenship and Immigration) [2004] FC 902 (23 June 2004) at [9] which overturned the decision on judicial review.

${ }^{119} \operatorname{Re} X$ [2006] CanLII 61633 (IRB) (27 March 2006)(Zimbabwe).

${ }^{120}$ Begum v Canada (Minister of Citizenship and Immigration) [2000] CanLII 16199 (FC) (29 September 2000)(Bangladesh).

${ }^{121}$ Referenced in Houssainatou v Canada (Minister of Citizenship and Immigration) [2002] FCT 2004 (26 November 2002) at [3] which overturned the decision on judicial review.

${ }^{122} \operatorname{Re} X$ [2001] CanLII 26949 (IRB) (2 February 2001)(China).
} 
- an Iranian woman maintained a 'strained' relationship with her parents after refusing an arranged marriage. ${ }^{123}$

A number of these findings reflect what Connie Oxford has called 'assumptions of discontinuity' in refugee determinations. ${ }^{124}$ Reflecting a male model of 'public' or state actor persecution, decision-makers are unable to accept that the persecuted person may continue to have a relationship with their persecutor/s, most especially if they are family members.

Many credibility or 'plausibility' findings were based squarely and solely on supposition and thus could not be falsified or verified by reference to any external indicator of likelihood in which case applicants ought properly to be given the benefit of the doubt under basic principles of refugee law. ${ }^{125}$ However there were also occasional decisions on credibility that could, and should, have been assessed by reference to country of origin evidence. Of these, the most troubling held on the basis of 'documentary evidence' that it was implausible that a girl would be married under the legal age of marriage in Bangladesh (18 years of age). ${ }^{126}$ This is a shocking finding, given that numerous international human rights agencies such as UNICEF and the UN Population Fund indentify Bangladesh as a major location of child marriage, with the majority of the female population married before the age of 18 , and indeed many before the age of $15 .^{127}$

\footnotetext{
${ }^{123}$ Referenced in Sadeghi-Pari v Canada (Minister for Citizenship and Immigration) [2004] FCJ 316 (26 February 2004) which overturned the decision on judicial review.

${ }^{124}$ C. Oxford, 'Protectors and Victims in the Gender Regime of Asylum' (2005) 17 NWSA Journal 18, 31.

${ }^{125}$ UNHCR, Handbook on Procedures and Criteria for Determining Refugee Status under the 1951 Convention and the 1967 Protocol relating to the Status of Refugees (UNHCR Handbook) (1992 edition) at [20]. See also Home Office (UK), Asylum Instructions on Assessing Credibility in Asylum and Human Rights Claims (c2007), 9; Canadian Refugee Protection Division, Assessment of Credibility in Claims for Refugee Protection (2004) at [1.3]; Australian Government, Migration Review Tribunal and Refugee Review Tribunal, Guidance on the Assessment of Credibility (2006, updated 2008) at [2.6].

126 Begum v Canada (Minister of Citizenship and Immigration) [2000] CanLII 16199 (FC) (29 September 2000)(Bangladesh).

${ }^{127}$ See eg UNICEF, 'Child Protection Information Sheet: Child Marriage' (2006) noting 65 per cent of women married before the age of 18; UNFPA, 'State of the World's Population: Child Marriage Fact Sheet' (2005) stating that 45 per cent of young women now aged between 25 and 29 had been married before 15. See also World Vision, 'Before She's Ready: 15 Places Girls Marry by 15' (2008) listing Bangladesh as the number one country with 52.5 per cent of the female population married before the age of 15 .
} 


\section{WHO WINS? THE SUCCESSFUL CLAIMS}

There were thirty-eight positive decisions in our data set. We counted as 'positive' decisions in which the outcome was what the refugee claimant sought at that stage. Yet judicial review decisions in all of the countries, and many tribunal level decisions in the UK, result in a redetermination of the claim, so positive decisions are not necessarily representative of substantively successful refugee outcomes. ${ }^{128}$ In short, counting 38 of our 120 decisions as positive is highly likely to over-represent the chance of 'success' for forced marriage refugee claimants.

Searching for commonalities among these claims is not easy, especially as many of the 12 judicial review decisions do not contain much detail about the claim and thus it is difficult to ascertain a clear picture of the underlying facts, or of the basis of the original decision maker's reasoning. The successful claimants come from 22 different countries in Europe, Asia, the Middle East and Africa, and include lesbians, gay men, heterosexual women and one of the two heterosexual men in the data set. At the level of broad statistical sweep, this serves only to reinforce that each refugee determination is an individual inquiry. The positive decisions reflected typical generic elements of positive decisions in other types of refugee cases, such as strong country information in support of the claimant's story and affirmative credibility findings. As noted earlier, in gay men's claims marriage itself was usually either framed or received as tangential to the major harm and many of the positive decisions were actually made on the basis that marriage or failure to marry would lead inevitably to the exposure of the applicant's sexuality: thus the actual persecution was seen to be on the basis of homosexuality rather than by virtue of marriage. ${ }^{129}$

\footnotetext{
${ }^{128}$ In addition, one of the positive judicial review decisions was later overturned on appeal: see $\mathrm{n} 103$ above.

${ }^{129}$ The sole successful outcome by a (presumed by the decision maker) heterosexual man facing forced marriage was a judicial review decision in the Canadian Federal Court, which held that it was not inherently implausible that a young Malian man would face forced marriage, and thus the findings of the IRB that only women were victims was unsound: Traore $v$ Canada (Minister of Citizenship and Immigration) [2003] FC 1256 (28 October 2003).
} 
The singularly most interesting factor in the positive cases is that forced marriage was in itself found to be a form of persecution in only 14 decisions. Even within these 14 cases the forced marriage claim was usually accompanied by 'something more', such as FGM, sexual and domestic violence, polygamy, levirate or sororat marriage. ${ }^{130}$ Of the entire pool of 120 decisions we were able to identify only four cases in which forced marriage alone was held to be persecutory. ${ }^{131}$ This is absolutely at odds with the characterisation of consent in marriage as a core international human right, and is stunningly out of step with the United Kingdom's domestic initiatives.

The tendency to exoticise gender claims, now well documented, ${ }^{132}$ was notable in examining the women's positive cases. For women success coalesced around two distinct themes, one being marriage as the site of other harms likely to occur as a result within or because of the relationship, usually FGM and less often domestic violence ${ }^{133}$ (sometimes both); the second

\footnotetext{
${ }^{130}$ The decisions that actually characterise forced marriage itself as persecutory are: MZXFJ V MIMA [2006] FMCA 1465 (10 October 2006)(Uganda); N95/10037 [1997] RRTA 623 (25 February 1997)(Bangladesh); N98/21046 [1999] RRTA 1872 (12 October 1999)(Jordan); N98/25465 [2001] RRTA 27 (12 January 2001)(Ghana); V0618399 [2006] RRTA 95 (22 June 2006)(Albania); 071426303 [2007] RRTA 132 (29 June 2007)(Saudi Arabia); Re X [2000] CanLII 21442 (IRB) (11 July 2000)(Nigeria); X v Canada (Immigration and Refugee Board) [2001] CanLII 26862 (IRB) (26 November 2001)(Central African Republic); X v Canada (Immigration and Refugee Board) [2001] CanLII 26862 (IRB) (26 November 2001)(Nigeria), Vidhani v Canada (Minister of Citizenship and Immigration) (TD) [1995] CanLII 3606 (FC) (8 June 1995)(Kenya); Traore v Canada (Minister of Citizenship and Immigration) [2003] FC 1256 (28 October 2003); Eimani v Canada (Minister of Citizenship and Immigration) [2005] FC 42 (17 January 2005)(Uganda); Houssainatou v Canada (Minister of Citizenship and Immigration) [2002] FCT 2004 (26 November 2002)(Guinea); and NS (Social Group) Afghanistan CG [2004] UKIAT 00328.
}

${ }^{131}$ The four decisions in which there was not clearly 'something more' in the claim such as FGM or polygamy in addition to the forced marriage are: Vidhani $v$ Canada (Minister of Citizenship and Immigration) (TD) [1995] CanLII 3606 (FC) (8 June 1995)(Kenya); Eimani v Canada (Minister of Citizenship and Immigration) [2005] FC 42 (17 January 2005)(Uganda); Houssainatou v Canada (Minister of Citizenship and Immigration) [2002] FCT 2004 (26 November 2002)(Guinea); and NS (Social Group) Afghanistan CG [2004] UKIAT 00328 in the UK. In two of those four cases (Eimani $v$ Canada and Houssainatou $v$ Canada) the decisions are judicial review with little known about the facts.

${ }^{132}$ See eg A. Macklin, 'Refugee Women and the Imperative of Categories' (1995) 17 Human Rights Quarterly 213; S. Razack, 'Domestic Violence as Gender Persecution: Policing the Borders of Nation, Race and Gender' (1995) 8 Canadian Journal of Women and the Law 45; J. Bhabba 'Internationalist Gatekeepers?: The Tension between Asylum Advocates and Human Rights' (2002) 15 Harvard Human Rights Journal 155; Oxford, n 124 above.

${ }^{133}$ See in particular C. Oxford's finding in the US asylum context that FGM was always assumed to constitute persecution whereas domestic violence was not: $\mathrm{n} 124$ above. 
being that the kind of marriage was sufficiently non-normative or 'foreign' to Western ideals of marriage that it was construed as distinctly harmful.

The influence of exoticising factors in the kind of marriage under consideration should not be underestimated: 11 positive decisions concerning women (both heterosexual and lesbian) involved marriages with one or more of the following factors: polygamy, a Muslim groom (when the applicant was Christian), a groom who was a generation or more older than the woman, bride price or marriage debt, levirate marriage (marriage to the woman's deceased husband's brother) or sororat marriage (marriage to a deceased sister's husband or fiancé). These practices are culturally remote from Western decision makers, and they correlated more closely with the positive than negative decisions. In contrast, domestic violence, a harm against women seen as 'common' in both refugee sending and receiving countries, ${ }^{134}$ was actually slightly more correlated to negative women's cases than positive ones.

In nine of the positive heterosexual women's claims, forced marriage was viewed as either a trigger for, or - less commonly - as part of a cumulative pattern of, persecution in which marriage became a site for other harms, in particular FGM. In this reasoning, forced marriage is only a harm because of its role in bringing about other more tangible forms of harm; implicitly forced marriage may have persecutory consequences rather than being in itself persecutory. One decision maker expressed this as follows:

Although there are three separate forms of harm which the applicant faces upon return to Ghana (forcible marriage, forced conversion to Islam and being denied the right to practice her religion and circumcision), I have decided to treat the harm as a whole rather than individually because in my opinion they are inextricably linked to each other and the second two harms are consequent upon the forced marriage. ${ }^{135}$

In two of the three positive decisions coming out of the United Kingdom, the claims involved an array of exoticising factors as well as subsequent or consequential harms. In $T B$, a young Iranian woman's politically powerful father required her to become a second wife to a 60 year old colleague of his to whom he owed a 'cultural debt'. The Tribunal found that if she

\footnotetext{
134 ibid.

135 N98/25465 [2001] RRTA 27 (12 January 2001)(Ghana), 17. See also N95/10037 [1997] RRTA 623 (25 February 1997)(Bangladesh) and N95/06944 [1996] RRTA 3480 (4 December 1996)(Bangladesh).
} 
were to return to Iran the applicant would be at risk of physical harm or death at her father's hands, and if she proceeded with the proposed marriage (under duress or by consent) she would be seriously harmed by the husband in retribution for her flight. Thus the decision addressed itself to harms which would arise after the claimant was forced to marry. In $R G$, the marriage in question was a levirate 'marriage by abduction' of a child. ${ }^{136}$

A few of the positive cases did provide examples of nuanced reasoning, analysing forced marriage itself as persecution without an undue focus on consequential or exoticising factors. These decisions suggest the possibility of breaking down the 'us' marriage and 'them' marriage distinction, and come closest to analysing marriage as it is seen in human rights settings. An early judicial review decision of the Canadian Federal Court succinctly demonstrates an appropriate approach. With reference to both international human rights standards and to the Canadian guidelines on gender related persecution, the court held that the originating tribunal erred because it failed to address the proper question by only asking whether the female claimant would face spousal abuse after the threatened marriage. Justice McKeown concluded,

women who are forced into marriages against their will have had a basic human right violated. There are United Nations conventions to which Canada is a party which state that the right to enter freely into marriage is a basic human right. ...it is not necessary for the Board [IRB] to look at whether the sanctions are so severe that they severely interfere with bodily integrity or human dignity. ${ }^{137}$

A 2007 decision from the Australian Tribunal similarly identified an act of forced marriage itself as a form of persecutory harm. While this case involved threats of death and a record of serious physical harm, the Tribunal nonetheless concluded:

that the forcible marriage of the applicant without her consent constitutes serious harm ... The Tribunal notes and accepts the country information set out above which indicates that while the authorities have taken some steps to protect women in Saudi Arabia from forced marriage the practice is still widespread and that the authorities are often complicit in this practice by reason of societal attitudes toward women. ${ }^{138}$

\footnotetext{
${ }^{136} R G$ (Ethiopia) v Secretary of State for the Home Department [2006] EWCA Civ 339.

${ }^{137}$ Vidhani v Canada (Minister of Citizenship and Immigration)(TD) [1995] CanLII 3606 (FC)(8 June 1995) (Kenya),

4. The Court returned the case to the Tribunal to be re-decided by a differently constituted panel.

${ }^{138}$ RRT Reference 071426303 [2007] RRTA 132 (29 June 2007) (Saudi Arabia), 16.
} 
In the one UK decision where forced marriage itself was seen as a harm, NS, the tribunal demonstrated a remarkable ability to focus on forced marriage as the principal harm given a factual context which included ethnic and political persecution and a serious sexual assault. ${ }^{139}$ The Tribunal went so far as to note that the Afghan government had failed to criminalise forced marriage ${ }^{140}$ and considered both that the applicant ought not be forced into the specific marriage with which she had been threatened and that she ought not be generally compelled to marry in order to gain the protection of a man (and thus a safer life in Kabul). The Tribunal further considered that the applicant's two young daughters would also be at risk of forced marriage. ${ }^{141}$ It is noteworthy that one of the sitting members of the Tribunal in NS was Vice President Catriona Jarvis, who was one of the authors of the original 2000 UK Gender Guidelines (which have since been abandoned by the new tribunal).

While these 'best practice' decisions, or perhaps more accurately, best-practice-so-far decisions, do rely on human right standards, they do not go so far as to engage with ideas of individual autonomy and choice. In our view, human rights standards are an important step, but still represent a very thin vision of autonomy and self-determination. In this regard, it is instructive to contrast even the most successful forced marriage refugee claims with the work of the Forced Marriage Unit in the UK. It is to this contrast that we now turn.

\section{THE FORCED MARRIAGE UNIT}

Britain's Forced Marriage Unit is a stunning example of a Western government embracing an ideologically charged defence of freedom to marry as a human right. In its own words, the unit is '...the only government unit in the world dedicated to investigating and helping people escape forced marriages. ${ }^{, 142}$ The FMU was established in 2005 and is a joint initiative of the British Foreign and Commonwealth Office and the Home Office. The FMU is located in

\footnotetext{
${ }^{139}$ NS (Social Group) Afghanistan CG [2004] UKIAT 00328.

${ }^{140}$ NS (Social Group) Afghanistan CG [2004] UKIAT 00328 at [61].

${ }^{141}$ NS (Social Group) Afghanistan CG [2004] UKIAT 00328 at [96].

142 Foreign and Commonwealth Office, 'Forced Marriage Unit' at http://www.fco.gov.uk/en/fco-inaction/casestudies/forced-marriage (last visited 27 May 2009). This includes bringing wardship applications on behalf of minors, see eg SB and RB [2008] EWHC 938 (Fam).
} 
the Foreign and Commonwealth Office (FCO) and grew out of the earlier 'community liaison' unit operative in that department since $2000 .{ }^{143}$ The Unit has a staff of seven based in London and it works with overseas consular staff as required. A statutory guidance document accompanying the new legislation states that in the first nine months of 2008, 1,300 'instances of suspected forced marriage' were reported to the FMU. ${ }^{144}$ In terms of ongoing case work, the FMU reports that it currently deals with around 400 cases annually. ${ }^{145}$

Uniquely, the Forced Marriage Unit has developed a capacity to act overseas to assist Britons and dual citizens facing forced marriage. The FMU coordinates consular staff abroad, intervening directly when the unit or consular staff are notified that someone is at risk of forced marriage, or has been forced to marry, overseas. By 2008 the unit had reportedly assisted with 180 such cases overseas. ${ }^{146}$ On the 'support British nationals abroad' page of the FCO website, the 'Forced Marriage' banner appears between 'The FCO in an emergency' (other examples include hurricanes, terrorism, and plane crashes) and 'Child Abduction.' The message is clear: we take this seriously. In the case study of 'Farah', featured on the FCO website in January 2009, consular staff in Islamabad intervened when Farah's boyfriend in the United Kingdom alerted the Forced Marriage Unit that something seemed wrong during Farah's trip to Pakistan to visit her dying grandfather. As recounted in the case study:

Later that same day, Farah contacted us from a friend's house. ...She pleaded with us to rescue her from the nightmare in which she had found herself.

Our rescue operation swung into action and within 48 hours our staff had got her out and brought her back to Islamabad. She had visible physical injuries where her brother and mother had attacked her and was extremely distressed.

\footnotetext{
${ }^{143}$ This unit also commissioned sociological research, see eg Y. Samad and J. Eade, 'Community Perceptions of Forced Marriage' FCO, Community Liaison Unit (2001).

${ }^{144}$ n 41 above, 5 .

145 Foreign and Commonwealth Office, 'Forced Marriage Unit' at http://www.fco.gov.uk/en/fco-inaction/nationals/forced-marriage-unit/forced-marriage (last visited 26 May 2009).

146 ibid.
} 
Back in the UK the FMU arranged for her boyfriend to send her the money for a flight home. The next day they were reunited at the airport and they are now happily married. ${ }^{147}$

The same case study offers the reassurance to Britons at risk overseas that the FMU deals with cases like this every week. In December 2008, the UK press reported that the FMU's rescue activities extended to a British resident non-national as well. ${ }^{148}$

A major aim of the unit is 'community education' which is broadly targeted, including brochures for people at risk of forced marriage (discussed below), 'awareness raising materials' for schools including a video (Tying the Knot' 2002), posters, brochures and cards directed at students and teachers $(2008)^{149}$, a national publicity campaign in 2006 ('You have the right to choose'), a half hour DVD on the FMU and its cases ('The Forced Marriage Unit' also released on YouTube, 2008) $)^{150}$ and close co-operation in the production of a BBC documentary which followed their rescue activities in Pakistan ('This World: Forced to Marry' December 2008). The FMU also hosts web links and regional contact information for a range of women's refuges and domestic violence services, and produces substantial training and policy documents for a range of professionals to detect and respond to forced marriage.

The FMU message appears feminist informed and relatively nuanced. For example the statutory guidance statement lists the 'key motives' behind forced marriage, the first of which is '...controlling unwanted sexuality (including perceived promiscuity, or being lesbian, gay, bisexual or transgender) - particularly the sexuality of women'. ${ }^{151}$ The LGBT brochure uses a series of personal stories concerning those forced to marry:

\footnotetext{
147 ibid.

${ }^{148}$ O. Bowcott and J. Percival, 'Bangladeshi "forced marriage” GP due back in Britain tomorrow' The Guardian 15 December 2008. See also In the Matter of a Child [2008] EWCH 1436 (Fam).

${ }^{149}$ See 'Forced Marriage - Awareness Raising Materials' at http://www.everychildmatters.gov.uk/resourcesand-practice/IG00331 (last visited 29 May 2009).

${ }^{150}$ See http://www.youtube.com/watch?v=AoGwwlFw20s (last visited 14 May 2009).

${ }^{151}$ n 41 above, 9.
} 
Sukhvinder was told that a relative was ill and was tricked into going to India. Once there, his family took his mobile phone, passport and money. The male members of his family told him that they knew about his sexuality, and that he would have to remain in India and marry a girl already chosen for him from the village. When he refused, they beat him.

Although I am gay, I wasn't really 'out' for a long time. I felt ashamed that as a man I was being forced into a marriage, and that my family was being violent with me. It was horrible for me and the girl I was forced to marry.

Sukhvinder managed to contact the British Consulate in India, who helped him return to the UK. Once home, the FMU put Sukhvinder in touch with organisations that have worked with him around issues of sexuality, depression and stress. ${ }^{152}$

In this FMU brochure, as in other FMU texts, the harm of forced marriage is directly linked to non-conforming sexuality; a perspective rarely seen in the refugee cases. The FMU emphatically and repeatedly articulates forced marriage as a practice which disciplines nonconforming sexuality and frequently notes that it is often used against adolescents and young adults whose families have become aware that they are involved in relationships of which the families disapprove. Policy initiatives include roles for schools and teachers, health care professionals, social workers, police, community organisations and individuals in being alert to and responding to situations of forced marriage. These policy initiatives articulate a 'protective' role of the state that extends to pro-active service provision.

The ideological context of the anti-forced marriage message comes through most clearly in the 'Forced Marriage Survivor's Handbook' ${ }^{153}$ The handbook aims to assist those who have decided to leave a forced marriage; it sets out basic advice about finding housing or refuge, managing finances, finding a job, repaying debts and returning to education. Like other FMU documents, it highlights survivor testimonials. Most interestingly, the handbook features many blank lined pages and encourages the reader to write her or his own plans and dreams on the facing pages of the bureaucratic advice. The first is prefaced with, 'Make some notes or write a description of your new life as you'd like it to be. You'll be able to look back on this - maybe adding to it from time to time - and it will help you stay focused and

\footnotetext{
${ }^{152} \mathrm{n} 50$ above, 4 (italics in the original).

${ }^{153} \mathrm{FMU}$, 'Forced Marriage Survivor's Handbook' (c 2007) at http://www.fco.gov.uk/resources/en/pdf/2855621/survivors-handbook (last visited 26 May 2009).
} 
motivated.' 154 The blank pages are framed with inspirational quotations: 'Turn your face to the sun and the shadows fall behind you'; 'You must be the change you wish to see'. The cover page of the volume is itself untitled, but quotes Lao-tzu, 'A journey of a thousand miles begins with a single step'. These currently popular quotations are employed here as the beckoning of empowered liberal individualism. The call to the diary mode of individual actualisation is the consciousness-raising precursor to the group orientation which is feminism. The marriage which is protected, valued, reified by Western law is the marriage of triumphant self-actualising individuals: precisely those who are the subjects and objects of human rights law. ${ }^{155}$ The way forward for those who are trapped in forced marriages is to become those on whom marriage cannot be forced. The introduction to the handbook reads:

Everyone has the right to choose who they marry and when they get married. You are not wrong for having made the brave decision to leave a forced marriage. This book will give you useful and practical information to help you take control of your life and focus on the future. ${ }^{156}$

The chasm between the image of forced marriage that appears in refugee law and the image of forced marriage portrayed by the Forced Marriage Unit is deep. Indeed refugee cases often come close to portraying forced marriage as a potentially unfortunate but inevitable consequence of pervasive cultural practices. Considering the expectation that all Bangladeshi men will marry and that the 'needs of the family and the community' outweigh those of the individual, one Australian case in 1998 stated,

While not advocating ... unwilling marriage ...it is fair to note that the Applicant [a gay man] is a member of a whole culture and has a continued allegiance to his Muslim faith, that is, he has not discarded all aspects of his culture as oppressive to himself. ${ }^{157}$

Here the decision maker recasts forced marriage as 'unwilling' and presents it as a situation which is not ideal, but not so damaging as to merit the kind of 'rescue' that being allowed to remain in a prosperous Western state provides.

\footnotetext{
${ }^{154}$ ibid, 4.

${ }^{155}$ See eg Razack's argument, in the context of forced marriage in Norway that it rationalises 'the colonial project as one of modern destiny', n 20 above, 149.

${ }^{156} \mathrm{n} 153$ above (printed on the unnumbered facing page).

${ }^{157}$ V97/06483 [1998] RRTA 27 (5 January 1998), 8. This refugee claim was rejected.
} 
It would be enlightening to directly compare refugee claims made in the United Kingdom with the case load of the FMU. This is simply not possible because there are only a handful of available UK cases, and because those cases devote so little analysis to the question of forced marriage. As we have argued above, the positive refugee decisions are almost never about forced marriage alone. The clear analysis of forced marriage as persecution in the lone case of NS has not been picked up by later UK decision-makers, nor has the frame of reference offered by the FMU apparently had any influence. While the legal content and political context of domestic forced marriage legislation and refugee law obviously differ, we would have expected to see at least some glimmer of shared understanding of the issues emerge in the UK in recent years.

There is no equivalent to the FMU in either Canada or Australia, where, despite large migrant communities (including from South Asia) a domestic political engagement with forced marriage has not yet emerged. ${ }^{158}$ Both Australian and Canadian governments have expressed concern about their citizens being forced into marriages while out of the country, but no domestic initiatives have materialised. ${ }^{159}$ This increases the depth of the paradox that it is UK refugee jurisprudence which is the most out of step both with international human rights standards and the more nuanced (if sometimes paternalistic) FMU understanding of forced marriage as a means of disciplining non-normative sexualities.

\section{CONCLUSION}

\footnotetext{
${ }^{158}$ The Canadian Department of Justice commissioned an overview of comparative legal approaches to forced marriage published in 2007, but did not take any further action. See: N. Dostrovsky, R. Cook and M. Gagnon, 'Annotated Bibliography on Comparative and International Law relating to Forced Marriage' (Department of Justice Canada, August 2007).

159 The Canadian government lists forced marriage as a concern for citizens travelling overseas (see http://www.voyage.gc.ca/faq/marriage-abroad_mariages-etranger-eng.asp\#11 (last visited 8 July 2009). See also reports of several teenage Australian girls approaching the Australian Embassy in Beirut for assistance in 2005, these claims for assistance were placed within the legislative frame of human trafficking: see P. Mercer, 'Australia Acts on Forced Marriage' BBC News, 3 August 2005, http://news.bbc.co.uk/2/hi/asiapacific/4740871.stm (last visited 8 July 2009).
} 
On the basis of our analysis of available refugee case law, we suggest that if many, perhaps most, of those individuals rescued abroad by the FMU were instead to make asylum claims of the United Kingdom, Australia or Canada on the basis of forced marriage, they would be refused. A striking illustration is the case of Humayra Abedin, a Bangladeshi national who was rescued from a forced marriage in Bangladesh through the combined efforts of the FMU and a Bangladeshi women's organisation (Ain O Salish Kendra). Although neither a British nor dual national, Humayra had been living in Britain for six years, first as a student and then as a trainee National Health Service doctor when her family tricked her into returning to Bangladesh in August 2008 in order to coerce her into a marriage she had previously rejected. The High Court of England and Wales issued a protection order on behalf of Humayra and she was ultimately brought before a court in Bangladesh which then placed her in the protection of police and British consular officers who assisted her to return to England two days later (where further protection orders were then issued to prevent her family from approaching her or attempting to remove her from the jurisdiction). ${ }^{160}$ Yet if Humayra had made a refugee claim it is extremely unlikely that she would have succeeded. Firstly, Humayra would have struggled within the UK jurisprudence both to articulate a particular social group and to argue that forced marriage itself constituted persecution. While she did suffer months of forced imprisonment, 'manhandling' and involuntary medication prior to the marriage, her account of the actual marriage ceremony was that she entered into it under 'emotional duress' rather than as a response to specific threats of violence. Moreover Humayra was not young, rural, poorly educated or financially dependent upon her parents. At the time of the marriage she was 32 years old, urban, educated (indeed a doctor with a Masters level education), had travelled and lived independently and was economically self-supporting; all factors that in numerous cases we examined were held to vitiate a claim to forced marriage or the inability to access state protection. In addition, like claimants held to be 'implausible' in other cases, Humayra continued to express love for the

\footnotetext{
${ }^{160}$ See eg Bowcott and Percival, n 148 above; P. Walker, 'NHS Doctor saved from Forced Marriage Gets Court Safeguards' The Guardian 19 December 2008; 'Statement from Humayra Abedin' The Guardian 19 December 2009.
} 
parents who had put her through this ordeal, 'they are still my parents. I do not have any bad feelings against them, any grudges'. ${ }^{161}$

This discordance underlines that refugee law is only ever partially about human rights protection, that it recognises some types of human rights violations more keenly and more regularly than others, and that it embeds a persistent cultural relativism. In refugee law, forced marriage appears to be characterised largely as an understandable offshoot of 'culture', the defining characteristic of the 'other'. This was true in cases in all three of the countries we examined, but was most in stark in the UK. Furthermore, the contrast seen here demonstrates that while the British government has moved away from the blunt instrument of immigration restrictions as a response to forced marriage, the double standard of 'marriage for us' and 'marriage for them' continues to flourish in British asylum law. While refugee law is sometimes viewed as part of the system of human rights law, in this light it is shown to be an effective immigration law screen above all, used as a border enforcing mechanism against individuals who, if they had legal immigration status in Britain, would be entitled to state sponsored rescue and support.

The image of the strong, benevolent state rescuing victims of forced marriage through the overseas reach of the FMU is the antithesis of refugee law, where Western states defend themselves through a variety of means aimed at limiting flows of asylum seekers to their borders. Refugee law seeks to reinforce borders; the FMU acts in spite of them. This contrast is hard to square. But it seems that those in need of 'rescue' have already become enough 'us' to merit higher human rights consideration than their cultural, or even national, counterparts. It may simply be that proximity does generate affiliation, even as immigration policy-makers fret that assimilation is elusive. It may also be that many of the states where FMU missions are accomplished are part of the former British 'empire', and that here the reach of the benevolent British state is enmeshed in Western (post)colonial practice. It is this that complicates any reaction to the FMU: in its work the victims of forced marriage are

\footnotetext{
${ }^{161}$ Walker ibid, see also 'Statement' ibid, 13, 'She retains a natural love for her parents despite their treatment of her' and 17, 'She does not wish for her parents to suffer any punishment for what has been done to her'. Note also that one of the first women to gain a forced marriage protection order under the UK legislation against her father continued to live with her family subsequently: L. Collins, 'Woman uses new Forced Marriage Laws against Father' The Independent 10 February 2009.
} 
hobbled by culture and exhorted to liberal individualism, but they are nonetheless welcomed among us, urged to become more us, encouraged to replace the support of the no-longer-welfare state for that of traditional family. This tentative analysis also helps us see why refugee law struggles so with forced marriage: the 'marriage' part of the equation is not quite 'other' enough to fit the refugee framework. 